\title{
PENGARUH STRATEGI PEMBELAJARAN PENINGKATAN KEMAMPUAN BERPIKIR (SPPKB) TERHADAP KEMAMPUAN BERPIKIR KRITIS PESERTA DIDIK
}

\author{
Akbar Handoko $^{1 *}$, Nanang Supriadi ${ }^{2}$, Septia Ningrum ${ }^{3}$ \\ ${ }^{1,3}$ Pendidikan Biologi, Universitas Islam Negeri Raden Intan Lampung, Indonesia \\ ${ }^{2}$ Pendidikan Matematika, Universitas Islam Negeri Raden Intan Lampung, Indonesia \\ *Email: akbarhandoko@ radenintan.ac.id
}

Received: Oktober $3^{\text {th }}, 2019$. Accepted: November $2^{\text {nd }}, 2019$. Published: December $29^{\text {th }}, 2019$

\begin{abstract}
This Study aims to determine Critical thinking skills are scientific abilities possessed by each individual, Implementation of Biology learning in class XI Al-Azhar 3 Bandar Lampung High School is still focused on the teacher (teacher centered) and the presentation of the material is still one-way and lacks training and accustoming students to critical thinking.This study was a quasy experimental design with a posttest only control design. The population of this study were students of class XI at AlAzhar 3 Bandar Lampung. The sample used as many as 2 classes selected by random class techniques, namely class XI Science 4 as an experimental class with the application of learning strategies to increase thinking skills (SPPKB) and science class 1 as a control class with conventional learning strategies. Based on the results of data analysis and hypothesis testing that has been done, it can be concluded that there is a significant influence of learning strategies to improve thinking skills $(S P P K B)$ on the critical thinking abilities of biology students in class XI at Al-Azhar 3 Bandar Lampung High School. From the research obtained on the indicator of critical thinking with the highest value namely the indicator gives a simple explanation.
\end{abstract}

Keywords: Learning Strategies to Improve Thinking Ability (SPPKB); Critical Thinking Ability; Human Reproductive System

\begin{abstract}
Abstrak
Penelitian ini bertujuan untuk mengetahui Kemampuan berpikir Kritis dan Kemampuan ilmiah yang dimiliki oleh setiap individu, pelaksanaan pembelajaran Biologi di kelas XI SMA Al-Azhar 3 Bandar Lampung masih berfokus pada guru (teacher centered) dan penyajian materi masih bersifat satu arah serta kurang melatih dan membiasakan peserta didik untuk berpikir kritis. Penelitian ini merupakan penelitian quasy experimental design dengan rancangan posttest only control design. Populasi penelitian ini adalah peserta didik kelas XI SMA Al-Azhar 3 Bandar Lampung. Sampel yang digunakan sebanyak 2 kelas yang dipilih dengan teknik acak kelas, yaitu kelas XI IPA 4 sebagai kelas eksperimen dengan penerapan Strategi pembelajaran peningkatan kemampuan berpikir (SPPKB) dan kelas IPA 1 sebagai kelas kontrol dengan strategi pembelajaran konvensional. Berdasarkan hasil analisis data dan pengujian hipotesis yang telah dilakukan maka dapat disimpulkan bahwa terdapat pengaruh yang signifikan strategi pembelajaran peningkatan kemampuan berpikir (SPPKB) terhadap kemampuan berpikir kritis biologi peserta didik kelas XI di SMA Al-Azhar 3 Bandar lampung. Dari hasil penelitian yang diperoleh pada indikator berpikir kritis dengan nilai yang paling tinggi yaitu pada indikator memberikan penjelasan sederhana.
\end{abstract}

Kata Kunci: Strategi Pembelajaran Peningkatan Kemampuan Berpikir (SPPKB); Kemampuan Berpikir Kritis; Sistem Reproduksi Manusia. 


\section{PENDAHULUAN}

Transformasi di dunia pendidikan akan banyak berkembang untuk menghadapi era tersebut diperlukan peningkatan keterampilan berpikir kritis pada pembelajaran (Hasanah dkk.,2019). Selain itu keterampilan berpikir kritis juga memudahkan menyelesaikan masalah, dan kemampuan berpikir kritis memakai inti dalam berasumsi, menganalisis serta keterampilan intelektual (Euis Istianah 2013; Suarsana 2013; Asna 2014). Berpikir kritis dapat diterapkan pada peserta didik dan penafsiran strategi dan rencana yang digunakan menuntaskan persoalan dan pembelajaran (Berutu dkk. 2019). Disandarkan dengan hal tersebut untuk membantu peserta didik dalam meningkatkan kemampuan berpikir berpikir kritis dibutuhkan Strategi pembelajaran yang memuat rencana tindakan termasuk metode dan pemanfaatan sebagai sumber daya dalam pembelajaran (Endang 2015). Untuk mengatasi permasalahan peserta didik yang mempunyai kemampuan berpikir kritis dibutuhkan pendekatan pembelajaran yang membuat peserta didik lebih aktif dan dapat meningkatkan penalaran (Agustiana, Supriadi, dan Komarudin 2019; Kusairi 2012).

SPPKB mendukung peserta didik menerima masalah yang ada dengan adanya strategi pembelajaran inkuiri (SPI), supaya peserta didik tersebut dapat mencari dan menemukan materi pelajaran sendiri, sekaligus memiliki perbedaan yang mendasar. Pola pembelajaran SPPKB berbagi pengalaman pendidik kepada peserta didik sebagai titik tolak berpikir, bukan teka-teki yang harus dicari jawabannya seperti dalam pola inkuiri (Wina sanjaya 2006). Kesanggupan atau kecakapan para pengajar saat menciptakan suasana komunikasi yang edukatif antara pengajar dan peserta didik yang mencakup aspek kognitif, afektif, dan psikomotor (Gunawan 2015). Akan berlangsung dalam upaya mempelajari sesuatu berdasarkan perencanaan sampai dengan tahap evaluasi dan tindak lanjutnya agar tercapainya tujuan pengajaran. Strategi pembelajaran peningkatan kemampuan berpikir (SPPKB) mengikutsertaan peserta didik dalam keseluruhan proses pembelajaran (Triani Ratna Wuri) juga memberikan peran pendidik mengkondisikan suasana kelas yang terbuka yang harus saling menghargai, menempatkan peserta didik sebagai subjek bukan sebagai objek (Amri dan Ratnawuri 2016; Anisa, Waluyo, dan Hariani 2013; Puspaningtyas 2019).

Berpikir kritis juga yang harus dikembangkan dalam pembelajaran yaitu: fokus, alasan, kesimpulan, situasi, kejelasan dan pemeriksaan secara menyeluruh (Widodo 2016). 
Kemampuan berpikir kritis penting harus dimiliki peserta didik terutama dalam proses pembelajaran biologi (Sulistiyawati dan Andriani 2017). Supaya peserta didik mampu membuat atau merumuskan, mengidentifikasi, menafsirkan dan merencanakan pemecahan masalah. Peserta didik yang mampu mengidentifikasi masalah, mengevaluasi dan mengkonstruksi argumen serta mampu memecahkan masalah tersebut dengan tepat. Berdasarkan hal tersebut, penelitian yang sepadan dengan kemampuan berpikir kritis belum pernah diteliti dengan SPPKB (Mahmuzah 2015; Mudhofir dan Rusydiyah 2016).

\section{METODE}

Variabel penelitian ini terdiri dari dua variabel, yaitu variabel bebas dan variabel terikat. Variabel bebas pada penelitian ini yaitu strategi pembelajaran peningkatan kemampuan berpikir (SPPKB) dan variabel terikat yaitu kemampuan berpikir kritis. Penelitian ini menggunakan metode quasy eksperimen dalam bentuk postetst control only design, populasi pada penelitian ini adalah semua peserta didik ruang XI SMA Al-Azhar 3 di Bandar Lampung dengan jumlah 258 peserta didik yang tersebar di 8 kelas. Sampel yang digunakan sebanyak 2 kelas yang dipilih dengan (random sampling), yaitu kelas XI IPA 4 sebagai kelas eksperimen menggunakan strategi pembelajaran peningkatan kemampuan berpikir (SPPKB) dan XI IPA 1 sebagai kelas kontrol menggunakan strategi konvensional. Teknik pengumpulan data dilakukan dengan tes berbentuk uraian untuk mengukur kemampuan berpikir kritis peserta didik dan dokumentasi. Analisis data menggunakan prasyarat uji-t dengan uji normalitas menggunakan Liliefors dan homogenitasnya menggunakan, sedangkan untuk uji hipotesis menggunakan uji-t Independent.

\section{HASIL DAN PEMBAHASAN}

Berdasarkan penelitian yang telah dilakukan di SMA Al-Azhar 3 Bandar Lampung, untuk mengetahui pengaruh strategi pembelajaran peningkatan kemampuan berpikir (SPPKB) terhadap kemampuan berpikir kritis peserta didik pada materi sistem reproduksi pada manusia. Diperoleh data amatan nilai kemampuan berpikir kritis biologi kelas eksperimen dan kelas kontrol sebagai berikut: 
Tabel 1. Hasil Post-test Berpikir Kritis Peserta Didik Kelas Eksperimen dan Kelas Kontrol

\begin{tabular}{ccc}
\hline Nilai & Eksperimen & Kontrol \\
\hline Tertinggi & 94,44 & 86,11 \\
Terendah & 44,44 & 30,56 \\
Rata-Rata & 72,63 & 61,20 \\
\hline
\end{tabular}

Perbedaan pada kedua kelas tersebut berdasar Tabel 1 yaitu pada kelas eksperimen memperoleh nilai rata-rata 72,63 dan pada kelas kontrol dengan nilai 61,20. Hasil kelas eksperimen lebih tinggi dari kelas kontrol, sehingga dapat disimpulkan strategi pembelajaran peningkatan kemampuan berpikir (SPPKB) berpengaruh terhadap kemampuan berpikir kritis pada peserta didik.

Tabel 2. Hasil Uji Normalitas Post-test

\begin{tabular}{|c|c|c|c|c|}
\hline Karakteristik & Eksperimen & Kontrol & Indeks & kesimpulan \\
\hline$L_{\text {hitung }}$ & 0,073 & 0,058 & \multirow{3}{*}{$\left(L_{\text {hitung }} \leq L_{\text {tabel }}\right)$} & \multirow{3}{*}{$\begin{array}{c}\text { Data } \\
\text { berdistribusi } \\
\text { normal }\end{array}$} \\
\hline$L_{\text {tabel }}$ & 0,1519 & 0,156 & & \\
\hline Taraf Signifikan & \multicolumn{2}{|c|}{0,05} & & \\
\hline
\end{tabular}

Berdasarkan tabel 2 hasil normalitas nilai posttest kelas eksperimen dan kelas kontrol berdistribusi normal. Hal ini dapat dibuktikan dari perhitungan data yang menunjukan bahwa $L_{\text {hitung }}<L_{\text {tabel }}(0,073<0,1519)$ sehingga $H_{0}$ diterima. Kelas kontrol, memperoleh $L_{\text {hitung }}<L_{\text {tabel }}$ yaitu $0,058<0,156$ maka $H_{0}$ diterima.

Tabel 3. Uji Homogenitas Post-test

\begin{tabular}{ccc}
\hline Karakteristik & Eksperimen dan kontrol & Kesimpulan \\
\hline$F_{\text {hitung }}$ & 1,329 & Homogen \\
$F_{\text {tabel }}$ & 1,811 & $\left(F_{\text {hitung }}<F_{\text {tabel }}\right)$ \\
\hline Taraf Signifikan & 0,05 & \\
\hline
\end{tabular}

Berdasarkan hasil tabel 3 hasil analisis data uji homogenitas dan uji hipotesis diketahui bahwa. Hasil perhitungan dengan taraf signifikan 0,05 pada kedua kelas, mendapatkan $F_{\text {hitung }}=1,329$ serta $F_{\text {tabel }}=1,811$ sehingga $\left(F_{\text {hitung }}<F_{\text {tabel }}\right)$ dan dapat disimpulkan bahwa $\mathrm{H}_{0}$ diterima. 
Tabel 4. Uji Hipotesis

\begin{tabular}{ccc}
\hline Karakteristik & Kemampuan berpikir kritis & Kesimpulan \\
\hline$T_{\text {hitung }}$ & 4,896 & \multirow{2}{*}{$H_{0}$ ditolak dan $H_{1}$ diterima } \\
$T_{\text {tabel }}$ & 1,998 & \\
\hline Taraf Signifikan & 0,05 &
\end{tabular}

Berdasarkan data yang terdapat pada Tabel 4 perhitungan menggunakan rumus Independent t-test menggunakan rumus 4,896 >1,998 $\left(T_{\text {hitung }}>\mathrm{T}_{\text {tabel }}\right)$, berarti $\mathrm{SPPKB}$ berpengaruh signifkan pada kecakapan berpikir kritis peserta didik kelas XI SMA Al-Azhar 3 Bandar Lampung.

Berdasarkan penelitian yang sudah dilakukan dan terkumpul data hasil penelitian serta dianalisis oleh peneliti, maka diketahui bahwa strategi pembelajaran peningkatan kemampuan berpikir (SPPKB) mempengaruhi kemampuan berpikir kritis peserta didik. Pengaruh ini diketahui dari hasil uji hipotesis yang memperoleh $t_{\text {hitung }}$ lebih besar daripada $t_{\text {tabel }}$. Pada $t_{\text {hitung }}$ memperoleh nilai sebesar 4,896 dan $t_{\text {tabel }}$ sebesar 1,998. Sehingga dapat disimpulkan $H_{0}$ ditolak dan $H_{1}$ diterima selain dari perolehan uji t dapat dilihat pula dari perolehan persentase nilai indikator yang diperoleh kelas eksperimen jauh lebih tinggi dibanding kelas kontrol perolehan nilai yang lebih tinggi pada kelas eksperimen dikarenakan pada strategi pembelajaran peningkatan kemampuan berpikir (SPPKB) yang digunakan memberikan kesempatan pada peserta didik untuk mengembangkan kemampuan berpikir kritisnya.

Strategi pembelajaran peningkatan kemampuan berpikir (SPPKB) merupakan strategi pembelajaran yang bertumpu kepada pengembangan kemampuan berpikir peserta didik melalui telaah fakta-fakta atau pengalaman anak sebagai bahan untuk memecahkan masalah yang diajukan (Ahmad Tohri) Strategi pembelajaran peningkatan kemampuan berpikir (SPPKB) terdiri dari enam tahapan yaitu, orientasi, pelacakan, konfrontasi, inkuiri, akomodasi, dan transfer.

Tahap pertama yaitu orientasi, pada tahap ini pendidik mengkondisikan peserta didik pada posisi siap untuk melakukan pembelajaran. kegiatan yang dilakukan pada tahap ini yaitu mengkondisikan peserta didik agar suasana pembelajaran kondusif dan responsif. Pendidik menyampaikan topik atau tema yang akan dipelajari yaitu materi sistem reproduksi manusia. Kesiapan belajar merupakan suatu kondisi awal seseorang yang sudah 
dipersiapkan untuk memberikan respon atau jawaban dalam mencapai tujuan pembelajaran tertentu dengan serangkaian kegiatan misalnya membaca, mengamati, mendengarkan dan pengalaman. (Ita Dwi Lestari) Tahap orientasi juga dilakukan dengan menjelaskan tujuan pembelajaran dan menjelaskan proses pembelajaran yang harus dilakukan peserta didik. Pemahaman peserta didik terhadap arah dan tujuan yang harus dicapai dalam proses pembelajaran sangat menentukan keberhasilan SPPKB.

Tahap kedua pelacakan yaitu tahapan pelacakan untuk memahami pengalaman dan kemampuan dasar peserta didik sesuai dengan tema atau pokok persoalan yang akan dibicarakan. Melalui tahapan ini pendidik dapat mengembangkan dialog dan tanya jawab. Tahapan ini dapat dilakukan dengan pendidik memberikan pertanyaan untuk merangsang kemampuan berpikir kritis peserta didik guna merespon rasa ingin tahu tentang pertanyaan yang diajukan. Dengan berbekal pemahaman itulah selanjutnya pendidik menentukan bagaimana ia harus mengembangkan dialog dan tanya jawab pada tahapan-tahapan selanjutnya. Melalui kegiatan pengembangan dialog dan tanya jawab peserta didik dapat melatih kemampuan menganalisis pernyataan, mengajukan dan menjawab pertanyaan yang diberikan sehingga indikator memberikan penjelasan secara sederhana dapat dikembangkan. Sesuai penemuan yang dilakukan (Lezy Luzyawati 2017) menyatakan indikator memberikan penjelasan sederhana dapat dikembangkan melalui kegiatan tanya jawab dan pengembangan dialog dengan peserta didik untuk memperoleh gambaran tentang pengetahuan maupun pengalaman yang telah dimiliki peserta berhubungan dengan materi yang akan dibahas (wike Indriani, Murtiani, Gusnedi 2014)

Tahap ketiga yaitu tahap konfrontasi merupakan tahap penyajian persoalan yang harus dipecahkan sesuai dengan tingkat kemampuan dan pengalaman peserta didik. Untuk merangsanag peningkatan kemampuan peserta didik pada tahapan ini, Pendidik dapat memberikan persoalan-persoalan yang dilematis yang memerlukan jawaban atau jalan keluar. Melalui kegiatan pengembangan penyajian persoalan yang harus dipecahkan sesuai dengan tingkat kemampuan dan pengalaman peserta didik dapat melatih dalam mengeksplorasi, Hal ini sesuai dengan penemuan yang dilakukan Sanusi yang menyatakan indikator membangun keterampilan dasar dapat dikembangkan upaya untuk mengajari peserta didik dalam proses berpikir, pendidik dituntut untuk menekankan peserta didik pada keterampilan berpikir. (Marniawati 2019) tahap konfrontasi menjelaskan bahwa tahap 
penyajian persoalan yang harus dipecahkan sesuai dengan tingkat kemampuan dan pengalaman peserta didik (Ahmad Tohri 2011).

Tahap ke empat yaitu tahap inkuiri merupkan tahap terpenting dalam SPPKB, dimana peserta didik belajar berpikir yang sesungguhnya. Peserta didik diajak untuk memecahkan persoalan yang dihadapi, oleh sebab itu Pendidik harus memberikan ruang dan kesempatan kepada peserta didik untuk mengembangkan gagasan dalam upaya pemecahan persoalan. Pendidik disini mengarahkan peserta didik untuk membentuk kelompok-kelompok kecil, pendidik juga membagikan LKK yang akan diberikan oleh peserta didik, pendidik memfasilitasi, mengamati dan mendorong peserta didik untuk berpikir memecahkan persoalan yang telah cdiberikan pada tahap sebelumnya. Pendidik memberikan ruang dan kesempatan kepada peserta didik untuk mengembangkan gagasan dalam upaya pemecahan persoalan. (Ahmad Tohri 2011) sehingga peserta didik dapat mencoba menyelesaikan masalah yang diberikan oleh pendidik, hal ini sesuai dengan penemuan yang dilakukan Ibrahim yang menyatakan indikator mengatur strategi dan taktik sehingga peserta didik mampu memutuskan sebuah tindakan dan berinteraksi dengan orang lain. Hal ini sejalan dengan pendapat Zukmadini bahwa strategi bertanya digunakan oleh pendidik untuk mencapai tujuan pembelajaran, karena dapat membuat peserta didik lebih aktif dalam menyampaikan pendapat, berdiskusi menanggapi permasalahan, dan memberikan kesimpulan. (Bhakti Karyadi Dini Dwi lestari,Irwandi Anshori 2017).

Tahap kelima yaitu tahap akomodasi merupakan tahap pembentukan pengetahun baru melalui proses penyimpulan. Tahap ini peserta didik dituntut untuk dapat menemukan kata-kata kunci sesuai dengan topik atau tema pembelajaran. Tahap ini melalui dialog Pendidik membimbing agar peserta didik dapat menyimpulkan apa yang mereka temukan dan mereka pahami sekitar topik yang dipermasalahkan. Pada tahap ini pendidik membantu dan membimbing peserta didik dalam menemukan kata-kata kunci untuk menyimpulkan materi sistem reproduksi pada manusia peserta didik juga dapat menyimpulkan pembelajaran. Tahap akomodasi bisa juga dikatakan sebagai tahap pemantapan hasil belajar, sebab pada tahap ini peserta didik diarahkan untuk mampu mengungkap kembali pembahasan yang dianggap penting dalam proses pembelajaran. Hal ini sesuai dengan penemuan yang dilakukan Sanjaya yang menyatakan indikator membuat inferensi dapat dikembangkan melalui kegiatan mengkomunikasikan. Pada kegiatan ini peserta didik mampu menemukan kata-kata kunci sesuai dengan topik atau tema pembelajaran. (Wina 
Sanjaya) dalam proses pembelajaran, hasil belajar suatu hal yang diperoleh atau dicapai peserta didik. Abdurahman (Asep, 2013) mengemukakan bahwa :"hasil belajar pada penilaian ini adalah kemampuan kognitif, dimana peserta didik dapat mengetahui, memahami dan menerapkan hasil dari suatu pembelajaran yang diperoleh peserta didik tersebut. (Syarif Firmansyah, Minarni 2019).

Tahap terakhir atau Tahap keenam yaitu tahap penyajian masalah baru yang sepadan dengan masalah yang disajikan. Tahap transfer dimaksudkan agar peserta didik mampu mentransfer kemampuan berpikir setiap peserta didik, untuk memecahkan masalahmasalah baru. Tahap ini Pendidik memberikan tugas-tugas yang sesuai dengan topik pembahasan. Seperti yang telah dijelaskan maka ada beberapa hal yang harus diperhatikan agar pembelajaran dapat berhasil dengan sempurna khususnya bagi pendidik sebagai pengelola pembelajaran, model pembelajaran bersifat demokratis, oleh sebab itu pendidik harus mampu menciptakan suasana yang terbuka dan saling menghargai, sehingga setiap peserta didik dapat mengembangkan kemampuanya dalam menyampaikan pengalaman dan gagasan. Pada tahap ini menyatakan indikator membuat penjelasan lebih lanjut sehingga peserta didik mampu mengidentifikasi istilah, setelah adanya tahap transfer ini peserta didik dapat menstimulus keterampilan peserta didik untuk memecahkan persoalan yang baru yakni dengan menjawab pertanyaan atau menanggapi pertanyaan. Pada tahap ini peserta didik berpikir sesungguhnya mengenai suatu materi yang dipelajari, setelah itu pendidik memberikan masalah yang dipikirkan peserta didik. (Yani Kurnia Sapta Rika, Mahrizal, Ermaniati Ramli 2013).

Pembelajaran di kelas eksperimen memakai SPPKB, dengan memberikan strategi konflik yang berlandaskan masalah (Dasa Ismaimuza 2013). Hal ini menunjukan strategi yang lebih baik daripada pengaplikasian strategi konvensional dikelas kontrol. Proses pembelajaran dikelas kontrol masih terpusat pada pendidik, dan secara pasif peserta didik menerima pembelajaran. Sementara pada peserta didik sendiri tidak memiliki keterampilan yang sama pada setiap individunya mengakibatkan terbatasnya ide yang dikemukakan peserta didik.

Strategi pembelajaran peningkatan kemampuan berpikir (SPPKB) digunakan membuat peserta didik aktif terlibat pada saat kegiatan pembelajaran serta berpusat pada peserta didik (student centered) dapat diartikan sebagai proses dimana pendidik mengajak peserta didik dalam berdialog agar pendidik mengetahui Pengetahuan, kemampuan peserta 
didik (Yeni Darvina, Cici Ramayanti, Mawsril 2016) Serta keterampilan yang dimiliki peserta didik dapat dikembangkan jika situasi belajar terbuka. Sehingga peserta didik akan berpikir berbarengan guna meyakinkan dan menggambarkan bahwa setiap individu akan memahami jawaban. Kemampuan berpikir peserta didik kelas eksperimen sesuai degan fenomena pada teori, karena peserta didik dengan aktif menjawab permasalahan berupa pertanyaan dari pendidik sendiri dan terlibat aktif saat proses belajar mengajar berlangsung.

Menurut Muhibbin Syah menyatakan bahwa belajar merupakan bahwa belajar adalah proses yang memegang peranan sangat penting dalam setiap penyelenggaraan pendidikan. Belajar yaitu suatu proses yang menghasilkan perubahan dalam memperoleh pengetahuan dan perubahan tingkah laku seseorang (Nining Kurniasih, Nukhbatul Bidayati Haka 2017). Analisa hasil proses belajar di kelas eksperimen menggunakan SPPKB berpengaruh pada kemampuan berpikir kritis peserta didik daripada kelas kontrol menggunakan strategi konvensional, hasil diperkuat dari hasil posstest, dari hasil $t_{\text {tabel }}$ Maka dapat menjawab hipotesis bahwa $h_{1}$ diterima ialah adanya pengaruh pada SPPKB terhadap kemampuan berpikir kritis peserta didik materi sistem reproduksi kelas XI IPA 4 di SMA Al-Azhar 3 Bandar Lampung.

\section{SIMPULAN DAN SARAN}

Simpulan pada hasil penelitian ini hasil analisis data yang didapatkan yaitu ada pengaruh yang signifikan pada strategi pembelajaran peningkatan kemampuan berpikir (SPPKB) terhadap kemampuan berpikir kritis peserta didik kelas XI IPA 4 SMA Al-Azhar 3 Bandar Lampung.

Saran yang dapat diberikan pada penelitian selanjutnya adalah strategi pembelajaran peningkatan kemampuan berpikir (SPPKB) diterapkan terhadap kemampuan berpikir lainya, dan pada materi yang lebih luas.

\section{DAFTAR PUSTAKA}

Agustiana, Nia, Nanang Supriadi, dan Komarudin Komarudin. 2019. "Meningkatkan Kemampuan Penalaran Matematis dengan Penerapan Pendekatan Bridging Analogy Ditinjau dari Self-Efficacy." Inovasi Pembangunan: Jurnal Kelitbangan 7 (1): 6161. 
Amri, Reisa Farida, dan Triani Ratnawuri. 2016. "Pengaruh Penggunaan Strategi Pembelajaran Peningkatan Kemampuan Berpikir (Sppkb) Terhadap Hasil Belajar Kewirausahaansiswa Kelas XI Semester Genap SMK Muhammadiyah 2 Metro TP 2015/2016.” PROMOSI: Jurnal Program Studi Pendidikan Ekonomi 4 (1).

Anisa, A., Joko Waluyo, dan Sulifah Aprilya Hariani. 2013. "Efektivitas Strategi Pemebelajaran Peningkatan Kemampuan Berpikir (Sppkb) Terhadap Hasil Belajar Dan Aktivitas Siswa Menggunakan Strategi Synargetic Teaching (Pada Mata Pelajaran Biologi Di SMP Negeri 10 Jember)." Pancaran Pendidikan 2 (4): 100110.

Asna, R. Hamidatul. 2014. "Implementasi Strategi Pembelajaran Berbasis Inkuiri dengan Siklus Belajar 5E untuk Meningkatkan Keterampilan Berpikir Kritis." Jurnal Penelitian Pendidikan 14 (2).

Berutu, Arfiena Fitria, Ani Sutiani, Angeline Viska Ayurosalia, dan Febiana Wulandari. 2019. "Inovasi Problem Based Learning dengan Strategi Pembelajaran Genius Learning Menggunakan Media Peta Konsep." Dalam Talenta Conference Series: Science and Technology (ST), 2:264-67.

Endang, Sri Endang Sri. 2015. "Penerapan Strategi Pembelajaran Tematik untuk Meningkatkan Kreativitas dan Hasil Belajar Siswa." Jurnal Paradigma Institut 1 (1).

Euis Istianah. 2013. "Meningkatkan Kemampuan Berpikir Kritis dan Kreatif matematik dengan Pendekatan model electing activities (Meas)pada siswa SMA.” Jurnal Infinity 2.

Gunawan, Imam. 2015. "Strategi Meningkatkan Kinerja Guru: Apa Program yang Ditawarkan oleh Kepala Sekolah." Dalam Prosiding Seminar Nasional Pengembangan Karir Tenaga Pendidik Berbasis Karya Ilmiah, Fakultas Ilmu Pendidikan Universitas Negeri Malang, 23:305-12.

HASANAH, Umi Nur, Andi Thahir, Komaruddin Komaruddin, dan Rahmahwaty Rahmahwaty. t.t. "MURDER Learning and Self Efficacy Models: Impact on Mathematical Reflective Thingking Ability." Journal for the Education of Gifted Young Scientists 7 (4): 1123-35.

Kusairi, Sentot. 2012. "Analisis asesmen formatif fisika sma berbantuan komputer." Jurnal Penelitian dan Evaluasi Pendidikan 16: 68-87.

Mahmuzah, Rifaatul. 2015. "Peningkatan Kemampuan Berpikir Kritis Matematis Siswa SMP Melalui Pendekatan Problem Posing." Jurnal Peluang 4 (1).

Mudhofir, Ali, dan Evi Fatimatur Rusydiyah. 2016. Desain Pembelajaran Inovatif dari teori ke praktik. Raja Grafindo Persada. 
Puspaningtyas, Nur Astuti. 2019. "Peningkatan Higher Order Thinking Skills (Hots) Melalui Strategi Pembelajaran Peningkatan Kemampuan Berpikir (Sppkb) Pada Pembelajaran EkonomI." Jurnal Pendidikan dan Ekonomi 8 (2): 134-41.

Suarsana, I. M. 2013. "Pengembangan e-modul berorientasi pemecahan masalah untuk meningkatkan keterampilan berpikir kritis mahasiswa." JPI (Jurnal Pendidikan Indonesia) 2 (2).

Sulistiyawati, Sulistiyawati, dan Cici Andriani. 2017. "Kemampuan berpikir kritis dan hasil belajar biologi berdasarkan perbedaan gender siswa." WACANA AKADEMIKA: Majalah Ilmiah Kependidikan 1 (2).

Widodo, Sigit. 2016. "Pengembangan Keterampilan Berpikir Kritis Peserta Didik Dengan Menggunakan Model Pembelajaran Berbasis Masalah (Problem Based Learning) Melalui Isu-Isu Sosial Ekonomi Pasca Penggenangan Waduk Jatigede Dalam Pembelajaran Ips Di Smpn 2 Wado Kabupaten Sumedang Kelas VIII C." International Journal Pedagogy of Social Studies 1 (2): 275-88.

Wina sanjaya. 2006. Strategi Pembelajaran. Disunting oleh M.Pd Prof.Dr.H.Wina Sanjaya. Pertama. Jakarta: Fajar Interprtama. 
BIOSFER: Jurnal Tadris Biologi Vol. 10 No. 2 (2019) 189 - 200

http://ejournal.radenintan.ac.id/index.php/biosfer/index
p-ISSN : 2086-5945

e-ISSN : 2580-4960

Desember 2019 